Article

\title{
Applying a Typology of Governance Modes to Climate Change Adaptation
}

\author{
Danny Bednar ${ }^{1, *}$ and Daniel Henstra ${ }^{2}$ \\ ${ }^{1}$ Department of Geography, Western University, London, N6A 3K7, Canada; E-Mail: dbednar@uwo.ca \\ 2 Department of Political Science, University of Waterloo, Waterloo, N2L 3G1, Canada; E-Mail: dhenstra@uwaterloo.ca \\ * Corresponding author
}

Submitted: 22 February 2018 | Accepted: 1 June 2018 | Published: 27 September 2018

\begin{abstract}
Climate change adaptation is a complex field of public policy that requires action by multiple levels of government, the private sector, and civil society. In recent years, increasing scholarly attention has been focused on the governance of adaptation, which has included exploring alternatives to state-centric models of decision-making and identifying appropriate roles and responsibilities of multiple actors to achieve desired outcomes. Scholars have called for greater clarity in distinguishing between different approaches to adaptation governance. Drawing on the rich scholarship about public governance, this article articulates and applies a typology of four modes of governance by which adaptation takes place (hierarchy, market, network, and community). Using examples of initiatives from across Canada, the article offers a framework for describing, comparing, and evaluating the governance of adaptation initiatives.
\end{abstract}

\section{Keywords}

climate change; adaptation; governance; typology; Canada

Issue

This article is part of the issue "Multidisciplinary Studies" in Politics and Governance.

(C) 2018 by the authors; licensee Cogitatio (Lisbon, Portugal). This article is licensed under a Creative Commons Attribution 4.0 International License (CC BY).

\section{Introduction}

Climate change is a global problem that has impacts on all sectors and demands adaptive responses from both public and private actors. Climate change adaptation is a complex policy area that requires "effective and simultaneous management and coordination of both topdown and bottom-up approaches" (Dickinson \& Burton, 2011, p. 103). Summarizing the state of adaptation planning and implementation in the Fifth Assessment Report of the Intergovernmental Panel on Climate Change, Mimura et al. (2014, p. 873) wrote:

As adaptation activities progress, many challenges have emerged, such as how to manage the decisionmaking process, how to develop strategies and plans, and how to implement them. In this regard, the roles within multilevel governance become an issue, such as horizontal coordination among different agencies and departments, and vertical coordination of various stakeholders from regional, national, to local actors.
These vertical and horizontal coordination challenges have sparked growing interest in "adaptation governance", defined here as the patterns of coordination among actors, including the direction of authority and the dominant instruments used to achieve objectives. Recent research has analyzed the coordination of adaptation initiatives that emerge in a top-down (i.e., statedirected) and bottom-up (i.e., locally mobilized) fashion (Bauer \& Steurer, 2014; Wellstead, Howlett, Nair, \& Rayner, 2016), explored the process of problem definition and timing (Huitema et al., 2016), and analyzed policy instruments and instrument selection (Henstra, 2016; Mees et al., 2014). Adaptation governance scholars have sought to make sense of a complex environment involving multiple levels of government, fragmented resources and responsibilities among public, private, and civil society actors, and overlapping networks of activity. Mapping out a research agenda on adaptation governance, Huitema et al. (2016, p. 13) argued that "'governors' in the climate adaptation domain need to define the problems they face, choose at what jurisdic- 
tional level action will be undertaken, decide when action will be taken, and through which modes of governance and instruments".

The configuration of actors and their roles in adaptation initiatives must be made clear in order for analysts to describe, compare, and critique governance arrangements. Much of the existing scholarly literature on adaptation assumes that it is, or should be, governed through complex networks of interdependent actors. As the typology presented here demonstrates, however, polycentricity and equality of input between state and non-state actors is only one ideal vision of adaptation governance. Networks, like all modes of governance, have considerable weaknesses, so considering the characteristics and dynamics of other modes of governance is useful to identify alternative governance arrangements. Governance analysis must allow for "closing off" of distinct visions in order for analysis and comparison of alternatives to be viable. To paraphrase Thompson (2003), for governance to mean anything, it cannot mean everything. When analyzing adaptation governance, therefore, scholars could benefit from a typology that describes and differentiates between multiple modes of governance through classification.

In this article we argue that the study of adaptation governance can be assisted by drawing on the broader theoretical and conceptual exercises that have defined the field of public governance. Topics such as whether complex societal problems ought to be approached from the bottom-up or the top-down, the nature of actor networks, the choice of policy instruments, directions of authority, and the deliberative process behind policy choices, have been the purview of governance scholars for decades. We propose that a typology of governance modes, which focuses on distinguishing actor roles, instrument selection, and direction of authority, holds value in making sense of adaptation governance for descriptive, comparative, and critical purposes.

The typology dates to Weberian analysis of state bureaucracies, and it has been further refined by many scholars (e.g., Bevir, 2012; Frances, Levacic, Mitchell, \& Thompson, 1991; Hall, 2011; Meuleman, 2008; Powell, 1991; Tenbensel, 2005; Thompson, 2003). Each mode of governance within the typology embodies a distinct view of societal coordination via the role of the state and other actors. While it is far from novel, it has been fruitfully applied to other complex policy domains such as policing (Fleming \& Rhodes, 2005), waste (Bulkeley, Watson, \& Hudson, 2007), and tourism (Hall, 2011). However, it has yet to be applied to adaptation in a systematic way.

Typologies provide researchers with conceptual clarity and allow "the identification of discrete areas of politics, each area characterized by its own political structure, policy process, elites and group relations, power structures, and policymaking processes that differ according to the type of issue they deal with" (Hall, 2011, p. 442). The typology presented here offers researchers a framework for describing, comparing, and critically an- alyzing adaptation governance processes and structures across different impacts and sectors. Each mode of governance comprises an internal logic regarding state roles and acceptable instruments, so their explicit recognition allows for better contextualization of adaptation initiatives for comparison and critique. For the adaptation scholar, once a mode of governance has been identified, the typology, and the rich scholarship on which it is based, offers valuable empirical and theoretical literature to draw upon.

Crucially, the typology reveals key normative assumptions behind distinct visions of adaptation governance, as the four modes of governance rely on philosophical visions of state roles, policy instruments, and use of authority (Dixon \& Dogan, 2002). By elucidating the internal logics of each mode, the typology highlights the very political process of designing, steering, or allowing for adaptation governance, thereby contributing to opening up the "black box" of governance that has characterized much of the adaptation research to date (Biesbroek et al., 2015; Wellstead, Howlett, \& Rayner, 2013). Through their competing visions of acceptable social coordination, the rivalrous ideal governance modes represent discrete visions that when applied to a policy problem better facilitate the discussion of just how an issue should be governed (Meuleman, 2008).

The article begins by describing the four modes of governance, including their underlying logic, unique features, and strengths and weaknesses. It then applies these governance modes to climate change adaptation initiatives in Canada through review of public documents. By identifying four distinct approaches to extreme rainfall and sectoral adaptation initiatives, we demonstrate how the typology can be used to describe, compare, and critique adaptation governance arrangements.

\section{A Typology of Governance}

At the core of any mode of governance is the fundamental role of the state (Pierre, 2000), so the typology uses the relationship between actors and instruments to the state as a key metric of classification, recognizing that the state always maintains its monopoly on the use of force. This view is generally applied to all public governance typologies, many of which are variations of the original hierarchy, market, and network approaches (e.g., Steurer, 2013; Treib, Bahr, \& Falkner, 2007).

Before presenting the typology, a few clarifying points are in order. First, limits of such a typology are acknowledged. As Frances et al. (1991, p. 6) point out, the modes "do not attempt to explain everything in one grand intellectual sweep." They work instead to highlight different visions, values, and explicit expectations of governance. The typology presented below outlines the governance modes as ideal types, whereas in practice elements from more than one is typically present, and this "mixing" is often the source of both governance effectiveness and failure (Rhodes, 1997). 
Nonetheless, the distinction between ideal modes is significant enough that differences should matter to the policy scholar. It will be impossible to identify, or promote, effective adaptation governance strategies without an adequate means of distinguishing their forms, internal logics, and potential for conflict. As Tenbensel (2005, p. 277) put it, "these ideal types can then be used as heuristic devices for gaining a handle on the complexity of actual public management practices, which involve combinations and layering of different modes". Given the particular philosophy underlying each mode, they also provide insight into the very political claims about how an issue ought to be governed and which modes should be applied to which problems.

Second, the modes of governance outlined below may not capture the entirety of options for social coordination. However, after examining the combinations and sub-genres of each category, Meuleman (2008, pp. 20-21), writing before the introduction of community governance to the typology, concluded:

The use of the three ideal-types hierarchy, network, and market, provided that they are not presented as monolithic constructs but as sets of related characteristics with a distinct internal logic, can provide a basic analytical tool for understanding governance. The concepts of hierarchical, network, and market governance together offer a complete enough analytical framework for explaining the conflicts and synergies within and between governance approaches.

The identification of governance modes can vary not only in identifying "mixes" of these modes (as mentioned above and described in a few cases below), but also in shifts over time. Many adaptation initiatives emerge from the typical policy cycle (problem identification, deliberation, implementation, monitoring) and therefore might embody different governance modes throughout the process. In this article we focus on initiatives that have been carried out and are recognizable in public presentation. Nonetheless, it is recognized that governance entails both structure (institutions and actor and relations) as well as process (rules and implementation) (Börzel \& Risse, 2010). Here we focus largely on the latter through publicly available documents, which sometimes do not explicitly reveal full details regarding both structure and processes. The more detailed information an analyst can obtain regarding an adaptation initiative the more confidently the mode of governance can be described and critiqued. All four ideal modes of governance are described below.

\subsection{Hierarchical Governance}

Hierarchical governance involves nested levels of state authority, wherein each unit is subordinate to its vertical superior, and in which tasks are divided into more manageable forms (Bevir, 2012). In the realm of public gov- ernance, hierarchies involve a chain of command from elected officials, who set out strategic objectives which public servants then implement through state activities. Hierarchy is said to be a rational, effective model of organization, designed for clear purposes, with almost militaristic focus (Meuleman, 2008).

The primary actors in hierarchical governance are state officials and those with whom the state wishes to consult. The role of state organizations is determined by their place within the hierarchy, wherein authority moves from top to bottom. Non-state actors may be information providers but are "passive rule-takers" (Hall, 2011, p. 445). Dominant policy instruments are those typically associated with "command and control", including laws, regulations, permits, and state intervention into individual liberties (e.g., eminent domain). Elected officials and senior bureaucrats determine policy needs and set the agenda, while those in the lower ranks implement the decisions.

Although it is fashionable to present hierarchy as antiquated, there remain clear instances of hierarchical governance in modern democracies (Bevir, 2012). For instance, policy fields related to security, law enforcement, and public safety tend to have a strong hierarchical structure. As with all governance modes, this reflects what society deems is an appropriate (i.e., politically acceptable) means of coordinating social life.

Hierarchical governance has a number of strengths. First, it effectively secures democratic legitimacy via representation, in that power flows from those with an electoral mandate from voters. Second, hierarchical control deals effectively with complex tasks (like adaptation) by sub-dividing them and encouraging the development of expertise. On the other hand, hierarchy is inflexible, has difficulty addressing policy areas lacking a clear consensus about desired outcomes and, in some cases, can stifle innovation due to a lack of broader societal inputs (Dixon \& Dogan, 2002). Given the internal logic of hierarchical governance, the selection of policy instruments does not necessarily require input from producers or consumers, as requisite information is known, or developed, by the state. At stake in hierarchical governance is democratic responsiveness: if state mechanisms choose to ignore public input, they will exercise state authority with unmatched resistance, as is the case in authoritarian regimes.

\subsection{Market Governance}

The driving logic behind market modes of governance is that responses to complex issues are best coordinated through the "invisible hand of the market" or to a lesser extent, the use of market-driven behavioral change. Although markets rely on the state to protect property rights and legitimate currency, authority is dispersed amongst the individuals taking part in a transaction, meaning all market participants hold some influence over its direction. 
Steering in this mode is therefore not top-down from government, but the result of competition and negotiation among market actors. Competition and negotiation are determined by the nature of the markets, and the extent to which states intervene or are more "laissez-faire" (Thompson, 2003). In more interventionist versions of market governance, state instruments such as taxes, subsidies, and even regulations are used to steer market participants. In others, there is considerably less state involvement and governance is marked primarily by the processes of supply and demand. However, both forms of market governance can be distinguished from hierarchy because market principles shape interactions between actors and are the locus of authority in governing. Beyond basic rules set by the state to facilitate market mechanisms, consumers and producers (including governments) interact and negotiate the nature of the policy tools and determine market outcomes. The main actors of market modes of governance are market participants, and the state can be a participant, rule maker, or handsoff observer (Hall, 2011).

The key strength of market governance is that both "policy makers" and "policy takers" are empowered to influence policy decisions by their actions in the marketplace. This approach is said to be reflexive and responsive to changes in society, and reflects market ideals of individual choice (Marshall, 1991), especially in its more laissez-faire form (Thompson, 2003). The main limitation of the market mode of governance stems from the broader failure of market mechanisms to account for negative externalities (Levacic, 1991). Even in the more interventionist market modes, which are intended to reduce negative externalities, there is a risk of market failure. Furthermore, market governance is typically deemed inappropriate for coordinating services that are rights-based.

\subsection{Network Governance}

Networks were recognized towards the end of the twentieth century as a "third way" of governing and have been a significant focus of the governance literature since the 1980s (Bevir, 2012). In distinguishing networks from markets and hierarchies as a means of coordinating social order, Frances et al. (1991, p. 15) explained: "if it is price competition that is the central coordinating mechanism of the market and administrative orders that of hierarchy, then it is trust and cooperation that centrally articulates networks". Along with cooperation and trust, a central component of networks (or so-called "new modes of governance") is the plurality of inputs. In this sense the governance of issues benefits from the increased involvement of stakeholder groups, non-governmental organizations, and firms beyond those who are selfinterested (as is characteristic of market governance). Authority is then dispersed, flattened, and horizontal, and negotiated where appropriate for the benefit of all network actors.
As in market governance, the state is one actor among many, but with significant authority and legitimacy to set the rules of the network, which is sometimes called "metagovernance" (Jessop, 2004). However, the extent to which the state is present to steer can vary, and thus so can the form of networks (Börzel \& Risse, 2010). Typical policy instruments such as self-regulation, accreditation schemes, and codes of practice carry the distinct component of "trust" that is not necessarily found in hierarchical and market instruments (Hall, 2011). Network governance relies on an internal logic of shared concerns and interests, as well as a willingness to cooperate. Equality of participants in this network is seen as an ideal, assuming that each participant brings to the table some resources to address the issue.

Networks have several strengths as a mode of governance. They are more participatory, flexible, and can foster innovation to address difficult policy problems through the inclusion of a broader range of actors and novel ideas (Bevir, 2012; Provan \& Milward, 2001; Whelan, 2015). According to Rhodes (2000, p. 81), networks work best when "cross-sector, multi-agency co-operation and production is required" and "flexibility to meet localized, varied service demands as needed". As such, network approaches have been embraced as a possible solution to the cross-sectoral problems of adaptation (Baird, Plummer, \& Bodin, 2016).

However, network governance has significant limitations. First, the decentering of the state can threaten the democratic legitimacy of public policy, in that elected officials are no longer dominant, while those without a public mandate are empowered (Considine \& Afzal, 2011). In such a case, the network becomes a tool of powerful network players able to steer not only other actors, but the state as well, towards their desired policy outcomes (Börzel, 2011). Second, decentering the state limits the typical outcomes of networks to non-coercive tools, such as best practices and recommendations. Third, the flexibility of networks - the ability to take almost any form and include almost any actor-is sometimes considered a weakness of networks as much as a strength (Frances et al., 1991). Finally, networks are often elitist and unrepresentative due to their reliance on expert communicators and those with resources to bring to the network (Rhodes, 2000).

\subsection{Community Governance}

The notion of community governance was first proposed by Pierre and Peters (2000). Tenbensel (2005) explained that community governance embraces many of the same consensual and participatory ideals of network governance but steering rests at the local level. In some instances, influence might be pressed upwards in order to acquire resources for locally developed, but otherwise autonomous, policies (Hall, 2011). As Tenbensel (2005, p. 279) put it: "the emphasis is on a community of selfgovernance and the normative literature on this type of 
governance is closely connected to long-standing themes of subsidiarity and local control over localized problems".

Community governance essentially reverses the roles found in hierarchical governance, whereby community members and local governments develop policy. Within federations, higher level governments may then be "policy takers" who provide resources for local communities to implement locally-derived plans. Given the core principles of unity and cooperation, typical instruments in the community governance mode include open public deliberation, education campaigns to inform local participants, direct democracy, and voluntary uptake via civic commitment (Hall, 2011).

The key strengths of community governance are its ability to foster outcomes that are appropriate and customized to the local scale, as well as its procedural equity. For many environmental, cultural, and social policy issues, local autonomy is seen as the only way to avoid problematic policies developed at higher levels that are inappropriate for local conditions (Hall, 2011). Procedural equity is achieved through open and transparent deliberation. The deliberative policy process in this mode is rooted in ideals of direct democracy, the engagement of fellow community members, and fewer barriers to participation.

Community governance has limitations, however. Foremost, it is seen as idealist and expecting too much from local consensus (Hall, 2011). There is no doubt that the communicative rationale at the core of community governance is optimistic, and the ideal of local autonomy seems decreasingly possible in the 21 st century globalized world. Community governance may also suffer from the same imbalance of power as networks, providing the opportunity for limited interests within communities to steer governance towards certain issues and visions. Further, the community mode of governance challenges fundamental constitutional structures in multilevel political systems, such as federations. As Nederhand, Bekkers and Voorberg (2016) point out, community governance conceptualized as entirely distinct from the existing hierarchical "shadow of hierarchy" remains a challenge given the presence of structural relationships between communities and higher orders of governance. If community governance is truly autonomous from higher-level au- thorities, then there will be obvious limitations to what it can accomplish due to limited local resources. Thus, it is sometimes unclear as to how local actors intersect with state structures in community governance modes. However, what community governance chiefly provides to the typology is the capacity to conceptualize localized or upward-moving authority that is otherwise missing in the downward, circular, or flat directions of the other modes. The typology of ideal governance modes is presented in Table 1.

This section has identified and explained four idealtype modes of governance drawn from existing scholarship, each of which embodies a distinct vision of societal coordination, including the role of the state and appropriate policy instruments. Further, each mode presents distinct actor roles regarding the initiation and implementation of actions. The next section applies the governance modes to the policy field of climate change adaptation, offering a framework to analyze and evaluate adaptation governance across different impacts, sectors, and locations.

\section{Governance Modes and Climate Change Adaptation}

Scholars use different frames to analyze adaptation governance (Dewulf, 2013). Some frame adaptation as a response to climate change impacts, with research exploring how actors can prepare for, or are adapting to, climate-related hazards such as heatwaves (Wolf, Adger, Lorenzoni, Abrahamson, \& Raine, 2010) or urban flooding (Oulahen, Mortsch, Tang, \& Harford, 2015). A second framing of adaptation focuses on sectors, exploring efforts to adapt practices within specific sectors, such as agriculture (Bryant et al., 2000), conservation (Brooke, 2008), and water (Miller \& Belton, 2014). This section outlines how the typology of governance modes presented above can be used to analyze adaptation efforts focused on both particular impacts and within different sectors.

The primary means of identifying the dominant mode of governance around an adaptation initiative is through the key actors and policy instruments. The more familiar an analyst is with a case the more accurately he or she will be able to discern the nuanced mixes of the

Table 1. Typology of modes of governance.

\begin{tabular}{|c|c|c|c|c|}
\hline & Hierarchy & Market & Network & Community \\
\hline $\begin{array}{l}\text { Direction of } \\
\text { Authority }\end{array}$ & top-down & $\begin{array}{l}\text { circular (supply and } \\
\text { demand) }\end{array}$ & horizontal & bottom-up \\
\hline $\begin{array}{l}\text { Initiating and } \\
\text { Implementing } \\
\text { Actors }\end{array}$ & $\begin{array}{l}\text { federal, regional and } \\
\text { local governments }\end{array}$ & $\begin{array}{l}\text { government and } \\
\text { market actors }\end{array}$ & $\begin{array}{l}\text { government, private } \\
\text { sector, and non- } \\
\text { governmental experts }\end{array}$ & $\begin{array}{l}\text { citizens, community } \\
\text { groups, neighbourhood } \\
\text { associations }\end{array}$ \\
\hline $\begin{array}{l}\text { Dominant Policy } \\
\text { Instruments }\end{array}$ & $\begin{array}{l}\text { legislation and } \\
\text { regulation }\end{array}$ & $\begin{array}{l}\text { supply and demand; } \\
\text { government market } \\
\text { intervention }\end{array}$ & $\begin{array}{l}\text { negotiated agreements, } \\
\text { codes of practice, } \\
\text { voluntary programs }\end{array}$ & $\begin{array}{l}\text { self-regulation, } \\
\text { voluntary participation }\end{array}$ \\
\hline
\end{tabular}


modes involved throughout the entire adaptation process. Here we use document analysis to identify examples of each governance mode in response to the same impact or across different sectors. While our cases of adaptation initiatives are selected form the federal state of Canada, the typology holds value for any constitutional state with identifiable orders of government, a distinct private sector, and free-associating public and nongovernmental actors.

\subsection{Adaptation Governance and Climate Change Impacts: Extreme Precipitation}

Hierarchical governance is a feasible means to coordinate adaptation across sectors and scales when a government has authority to command the behavior of societal actors or other governments. In the case of the City of Toronto, a municipal bylaw was passed requiring homeowners and businesses to disconnect downspouts from the city's stormwater sewer system. The program began as a voluntary initiative in 1998 but was amended to a requirement in 2007 due to increased risks of urban flooding (City of Toronto, 2018). The policy is enforced through fines for non-compliance and is monitored by city bylaw officials. The downspout disconnection program is a clear example of state authority exercised to deal immediately with a risk to infrastructure with relative certainty in outcome. The policy was developed in response to instances of basement flooding, and increased costs to the city through the early 2000s (City of Toronto, 2007a). Reports show that city officials recognized the voluntary initiatives were insufficient even after considerable effort had been invested in door-to-door awareness building campaigns (City of Toronto, 2007a). Community input was facilitated through the awareness-building campaign, but a decision was eventually made to pursue a mandatory disconnection program after analysis of cost to the city and residents as estimated internally by Water Toronto (City of Toronto, 2007a). In this case, the state (the City of Toronto) identified a problem, developed a solution internally within its jurisdictional capacity, and employed a coercive policy instrument with predictable and measurable outcomes. The downspout disconnection program is clear example of hierarchical governance in response to climate change where the implementing actor is the state, the policy tool is regulatory, and authority moves downward.

Market-based governance responses to adaptation are reflected in state intervention in market processes via programs to subsidize or incentivize action, while actual responses and implementation are left to consumers and producers. For example, responding to climate change-induced extreme rainfall, the City of Toronto initiated a Basement Flooding Protection Subsidy Program, which provides public funds to encourage the installation of a backwater valve for basements that are connected to the city stormwater system (City of Toronto, 2017a). Similarly, the City of Mississauga's stormwater charge combats increased urban rainfall by levying a fee on each property based on its impermeable surface area (City of Mississauga, 2017). In these examples, the state employed a market-based tool to incentivize adaptation among property owners (i.e., reducing stormwater discharge), and implementing actors are market participants.

While the City of Mississauga's approach was largely state-driven, the choice of a taxation policy instrument relies on the internal logic of market governance. In both cases, recognition of the need for an adaptive measure to reduce overland flow emerged from instances of flooding in the Greater Toronto Area. In the Mississauga case, the approach was taken to influence citizen behavior and accrue funds for infrastructure improvements, and the taxation (seen as a user fee) was preferred over a property tax increase to raise the same funds (City of Mississauga, 2012). The program was developed in a traditional policy sense, whereby state directed public engagement sought feedback, but where the agenda was still focused and not co-produced with other participants (AECOM, 2013). The City did not aim to intervene in property development or land use design directly, but rather to use the tax to steer market actors toward the use of permeable surfaces as a means to manage climate risk.

Network governance has commonly been promoted to address complex problems like climate change adaptation (Baird et al., 2016), and as a result has been popular in Canada with the provincial and federal orders of government. Much of the adaptation policy development witnessed in Canada and other states has emerged from intentionally designed networks of actors (Huitema et al., 2016). Between 2007 and 2011 the Government of Canada operationalized six Regional Adaptation Collaboratives (RAC) with a clear network logic of convening actors and sharing information around climate risks and possible adaptation responses (Henstra, 2017). Although the federal and provincial governments played a meta-governance role in developing the network, there was no intentional hierarchical structure, and neither regulatory nor market instruments were deployed or discussed at much length in RAC outputs. One of the RACs provides an example of a network approach to adaptation for extreme rainfall. The Prairie Regional Adaptation Collaborative (PRAC) was a group of government and non-government partners jointly funded by the Governments of Canada, Alberta, Manitoba, and Saskatchewan to "increase the capacity of municipal decisions makers to integrate climate adaptation into local planning decisions...by providing decision-makers with regionally relevant policies, networks, knowledge, and tools" (Parry, Taylor, Echeverria, McCandless, \& Gass, 2012 , p. 1). A review of PRAC's work on stormwater reveals that outputs were entirely information-based and voluntary tools were chosen to implement objectives, such as a resilience assessment framework for municipalities (Parry et al., 2012). In this case, a network of interdependent actors developed non-coercive, information- 
driven initiatives to address climate change, consistent with the logic of network governance (Hall, 2011).

Community governance is observed where actions are not driven by upper-level state structures, nor market forces or complex networks of cross-sectoral actors, but rather by place-based voluntary commitments (Hall, 2011). In the case of extreme rainfall, community governance is evidenced in low-cost, "grassroots" instruments that require no official sanction from a higher-level authority, and which are not driven by market forces. Such initiatives include public awareness campaigns to promote permeable driveways, increased greenspace, aid during extreme events, and property-level measures to capture and store stormwater (e.g., cisterns). Such activities are evidenced in the work of Community Resilience to Extreme Weather (CREW), a grassroots organization in the Greater Toronto Area, which trains local volunteers to help vulnerable neighbours in the event of extreme temperatures, floods, and storms (CREW, 2017). Other initiatives include awareness building and vulnerability mapping. CREW's organizational mandate makes direct reference to "faith and the common good", reflecting Jessop's (2011) vision of community governance as motivated by personal relationships and civic values. The CREW community group relies on activity without the coercion of the state, or even state presence, and actor behavior is not predominantly driven by market forces (CREW, 2017). Although CREW has engaged local state structures for resources, it maintains a grassroots, upwards movement of authority through community identified priorities. Voluntary actions to promote the resilience of neighbours and community services reflect a commitment to community and locally derived interests not facilitated or represented in other modes. The four governance modes and examples are summarized in Table 2.

\subsection{Adaptation Governance and Policy Sectors}

\subsubsection{Hierarchical Governance in the Building Sector} (Toronto)

A key component of hierarchical governance is that problems and desired goals must be articulated with relative certainty in order to legitimate command-and-control policy approaches (Hall, 2011). This means that some sectors, such as buildings and infrastructure, are more conducive to hierarchical adaptation governance than others, because they lend themselves more readily to quantification. In identifying hierarchical adaptation governance in a particular sector, an example can be found in Toronto's Green Standard program, adopted in 2010, which imposes on builders "a set of mandatory performance targets for the design and construction of new developments" (City of Toronto, 2017b). Authority flows down from the state to the building sector, members of which must implement the new requirements, which are enforced through the permit system. When the City of Toronto experienced an extreme rainfall event in 2013, the Green Standard program was adjusted to focus more on managing stormwater runoff for different categories of development (internal corporate, low-rise and residential, and mid to high-rise). The planning processes which must account for stormwater runoff are enforced through issuance of permits for construction which consider effective calculation of averted impact. The Green Standard program is a clear intervention of state capacity into a sector in order to foster adaptation, and it relies on an enforceable policy instrument to do so.

\subsubsection{Market Governance in the Agricultural Sector (Manitoba)}

Agriculture can be said to be an inherently adaptive and market-driven sector, because its activities are heavily influenced by weather and climate, and practitioners have long recognized how to alter their behaviour based on climatic conditions. Some governments appear to harness this adaptability and market logic, as evidenced in the Government of Manitoba's use of both government and private incentives, compensation, and insurance programs as the dominant instruments of adaptation governance (Manitoba Agriculture Risk Management Task Force, 2015). These include the private AgriInsurance, the federal AgriStability program, and the provincially operated AgriRecovery program. As a result, adaptation within the agricultural sector in Manitoba is driven mostly by government intervention into, or steering of, market behaviour and lack of regulatory command. The Agrilnsurance program provides insurance to producers in Manitoba against "uncontrollable natural perils" such as drought, flood, fire, and other haz-

Table 2. Modes of governance and adaptation to extreme precipitation.

\begin{tabular}{lllll}
\hline & Hierarchy & Market & Network & Community \\
\hline Action & $\begin{array}{l}\text { mandated } \\
\text { downspout } \\
\text { disconnection }\end{array}$ & $\begin{array}{l}\text { user fee for non- } \\
\text { permeable surfaces }\end{array}$ & $\begin{array}{l}\text { partnership building } \\
\text { and voluntary best } \\
\text { practices }\end{array}$ & $\begin{array}{l}\text { neighbourhood awareness } \\
\text { and volunteer extreme } \\
\text { weather event response }\end{array}$ \\
\hline Example & Toronto Mandatory & Mississauga & Prairie Regional & CREW Toronto \\
& Downspout & StormWater Charge & Adaptation Collaborative: & Extreme Weather \\
& Disconnection & Program & $\begin{array}{l}\text { Drought and Excessive } \\
\text { Moisture Theme }\end{array}$ & Volunteers Program \\
& Program & & . & \\
\hline
\end{tabular}


ards (Manitoba Agricultural Services Corporation, 2018). The program uses the economic instrument of publicly provided insurance to incentivize continued production of crops in the face of climate risks. However, the program is not mandatory and relies on the market incentive of producers recognizing risk and potential loss. In this sense the authority to adapt remains with market participants, meaning state authority is not exerted unless one enters the market. The Agrilnsurance program is not a command intervention by the state, nor a network of negotiation between the state and producers, as the Manitoba and federal governments are offering the service independently of producer uptake. The Agrilnsurance program does however reflect the mixing and shifting of modes as an initiative develops. The program's development emerged largely from public-private consultations in a more networked form (Manitoba Agricultural Risk Management Task Force, 2015), but the eventual initiative and policy instrument supporting it are decidedly market orientated.

\subsubsection{Network Governance across Policy Sectors} (Canada)

Network adaptation governance with a sectoral lens is evidenced most prominently in the Government of Canada's Adaptation Platform, a virtual community of practice designed to convene stakeholders for adaptation policy development and implementation. The Platform promotes partnership and dialogue, organized into nine specific working groups that have a sectoral lens (e.g., energy, infrastructure, and mining). Based on the outcomes of the Platform in 2016, a majority of the projects have generated either "best practices" or "state of knowledge" documents, such as vulnerability assessments and literature reviews (Natural Resources Canada, 2016). Numerous projects engage large numbers of partners, and many are led by "boundary organizations" such as the Pacific Climate Impacts Consortium (PCIC), which bring together public, private, and civil society actors as equal partners (Mimura et al., 2014). The initiating actors of such networked processes vary, including government officials, major NGOs, and industry associations. A review of all outcomes regularly published by Natural Resources Canada shows that aside from the state's role as convener, there are no coercive lead state ac- tors. Within the adaptation platform information development is paramount: sharing information around impacts and vulnerabilities and industry best practices for self-regulation are the dominant outcomes of the working groups (Natural Resources Canada, 2016).

\subsubsection{Community Governance in the Food Sector (Winnipeg)}

Community governance with a sectoral lens may evolve to address climate change vulnerabilities recognized at the smallest scales. In Winnipeg, Manitoba, for example, concern over climate impacts on the agricultural sector and food security amongst low-income residents have prompted local groups, such as Sustainable South Osbourne, to develop programs which foster urban resilience to climate-induced food disruption through community-run gardens (Sustainable South Osbourne, 2016). Consistent with community governance, the group looks to higher levels of government for resources rather than administration. A core principle of the organization is that the community knows best their environment and risks and they are the rightful stakeholders. In recent years the initiative has evolved to include academic partners under the name South Osbourne Permaculture Commons. Despite relations with state, academic, and private actors, the initiative remains committed to a community governance led by participants of the commons via direct democratic input. The chief instrument of action is awareness-building, particularly concerning the use of common property for food production in order to promote co-ownership and shared responsibility, as well as agricultural skills for future generations. The group distinctly emphasizes autonomy and independence even when resources are supplied from external sources. Consistent with community governance, projects are developed through open and participatory deliberation and are implemented by members. Although the projects might encourage action in other communities or at the provincial level, they remain focused on the community scale and voluntary actions of citizens. Notably, coercive state instruments are not present, and Sustainable South Osbourne is driven by a collective sharing of authority through deliberation. Table 3 illustrates how the four governance modes are evidences across policy sectors.

Table 3. Modes of governance and adaptation in policy sectors.

\begin{tabular}{lllll}
\hline & Hierarchy & Market & Network & Community \\
\hline Action & $\begin{array}{l}\text { mandatory construction } \\
\text { standards }\end{array}$ & $\begin{array}{l}\text { subsidies, insurance } \\
\text { and recovery funding }\end{array}$ & $\begin{array}{l}\text { best practices, state of } \\
\text { knowledge reports }\end{array}$ & $\begin{array}{l}\text { autonomous community } \\
\text { food production }\end{array}$ \\
\hline Example & Toronto Green Standard & Agrilnsurance, AgriStability & National Adaptation & Sustainable South \\
& & and AgriRecovery & Platform Mining, & Osbourne Permaculture \\
& & Programs in Manitoba & Infrastructure and & Commons \\
& & & Energy Working Groups & \\
\hline
\end{tabular}




\section{Conclusions}

\subsection{Descriptive, Comparative, and Normative Value}

Having shown the means by which analysts can identify adaptation modes of governance, it is important to again reflect on the value of such a typology. Adaptation researchers face multiple lenses through which to view the complex process of adaptation governance. The typology presented here provides discrete analytical categories in which to place the governance components of adaptation. By distinguishing among actor roles, policy instruments, and directions of authority, adaptation scholars have key indicators to identify the mode of governance at work in a particular sector or jurisdiction. In each case there are distinct modes of governance that can be referred to, and that are more manageable than relying on conceptualizing adaptation as complex and multiactor. Evidently each mode is complex and multi-actor, but in different ways, and with different strengths, weaknesses, and ramifications.

Further, the typology allows for comparison of important details of adaptation processes to better assess their transferability across impacts, sectors, or locations, and to assess the relationship between the state of adaptation and the ongoing modes of governance. For example, an effective adaptation program that is produced largely through hierarchical governance cannot be easily transposed to a location in which elected officials are unwilling to act on climate change. Recreating an adaptation strategy includes more than copying instruments; it requires understanding actor roles and interactions that lead to policy instrument choices and a grasp of how the governance arrangements led to the adaptive measure. In both Toronto and Mississauga, for example, flooding due to intense rainfall was addressed by the state, but with distinct logics. Both cities faced a choice about which governance mode and policy instrument would best deal with the impacts of extreme precipitation, and either could have chosen regulation or taxation. Focusing on the operative mode of governance and the outcomes of adaptation initiatives could illuminate ways to secure desirable adaptation outcomes and to replicate effective approaches across jurisdictions, sectors and scales. The typology provides a framework for comparison of these complex processes.

Other comparisons using the typology may include consideration of scale. As indicated by our examples, modes of governance for the same impact vary not only by location, but by scale. Will most other city governments approach extreme rainfall with market tools? Will higher-level governments consistently promote network approaches? As adaptation initiatives proliferate, typologies like the one we have outlined here will be valuable for analysts to compare varying approaches to similar impacts and across sectors.

Finally, as discussed above, the typology allows for clear identification of the politics of adaptation gover- nance. Modes of governance, and their implications for adaptation, are inherently related to visions of how society ought to be governed, and are therefore highly normative (Dixon \& Dogan, 2002, Hall, 2011). The typology provides a frame of reference to distinguish the values at the core of particular visions of governance. By advocating for one mode of adaptation governance over another, actors present a vision of how we should govern climate change adaptation and society. Recognizing this too will help bring adaptation out of the black box.

For instance, actors who promote the use of economic instruments (especially in the more laissez-faire version of market governance) reflect a belief that adaptation is not inherently a responsibility of the state, but an individual onus. Conversely, actors who promote the use of regulation or legislation are advancing ideals consistent with hierarchical governance: adaptation is a state responsibility and compliance is paramount, given the severity of the issue. These competing visions must be recognized in understanding the challenges of adaptation governance, which is clearly both a managerial and political problem. Any effort to replicate adaptation initiatives cannot ignore these normative components.

\subsection{Moving Forward}

In embracing the governance typology grounded in an already rich field of public policy research, adaptation scholars may find value in explanations of why some modes of governance do not work well with particular problems, or why a certain mix of modes simply will not work at all (Rhodes, 1997). Combining aspects of different governance modes might be problematic for normative reasons, such as described above, or because of competing internal logics of effective governance. In their application of the typology to policing in the UK and Australia, Fleming and Rhodes $(2005$, p. 203) argued that: "the future will not lie with either markets, or hierarchies or networks but all three. The trick will not be to manage contracts or steer networks but to mix the three systems effectively when they conflict with and undermined one another". Adding the community governance mode of typology, this future of mixing appears to be relevant to the field of adaptation. This mixing may ultimately be a role for governments, which are uniquely equipped with the authority, legitimacy, and resources to combine aspects of these governance modes. Recognizing the strengths and weaknesses that each mode embodies is a critical first step.

The added benefit of using a typology with such a long history is that the well-known strengths and weaknesses of the four modes can be considered when developing adaptation initiatives. It can be expected that the uncertainty surrounding many climate change impacts limits the utility of a hierarchical logic, and this uncertainty shifts expectations about policies, so the flexibility of networks may be necessary. However, the relative inefficiency of networks might make them insufficient to 
achieve the transformation required of major public infrastructure and economic behaviour in order to reduce vulnerability (Lonsdale, Pringle, \& Turner, 2015), so markets or hierarchy may be required. Finally, adaptation will not occur outside the contexts of community histories, geography, and values, so efforts must be developed while cognizant of even the smallest scales.

Ultimately, we hope that engagement with the typology, the internal logics of actor roles and appropriate policy instruments leads to increased conceptual clarity in the analysis of the governance of climate change adaptation, but also the politics of the governance of climate change. This article responds to the argument critique made by various scholars that adaptation governance is too often discussed with reference to structural functionalism and a "black boxing" of the political nature of governance (Biesbroek et al., 2015; Wellstead et al., 2013). We hope that in applying a well-developed typology of governance, the field can mature to better interrogate the processes, outcomes, and competing philosophies of actor roles, relations, institutions, and policy instruments in climate change adaptation.

\section{Acknowledgments}

The authors thank the Editor and anonymous reviewers for their helpful comments and suggestions.

\section{Conflict of Interests}

The authors declare no conflict of interests.

\section{References}

AECOM. (2013). City of Mississauga storm water financing study (Project Number 60247202). Kitchener: AECOM.

Baird, J., Plummer, R., \& Bodin, O. (2016). Collaborative governance for climate change adaptation in Canada: Experimenting with adaptive co-management. $R e$ gional Environmental Change, 16(3), 747-758.

Bauer, A., \& Steurer, R. (2014). Multi-level governance of climate change adaptation through regional partnerships in Canada and England. Geoforum, 51, 121-129.

Bevir, M. (2012). Governance: A very short introduction. Oxford: Oxford University Press.

Biesbroek, R., Dupuis, J., Jordan, A., Wellstead, A., Howlett, M., Cairney, . . . \& Davidson, D. (2015). Opening up the black box of adaptation decisionmaking. Nature Climate Change, 5, 493-494.

Börzel, T. A., \& Risse, T. (2010). Governance without a state: Can it work? Regulation \& Governance, 4, 113-134.

Börzel, T. A. (2011). Networks: Reified metaphor or governance panacea? Public Administration, 89(1), 49-63.

Brooke, C. (2008). Conservation and adaptation to climate change. Conservation Biology, 22(6), 1471-1476.

Bryant, C. R., Smit, B., Brklacich, M., Johnston, T. R., Smithers, J., Chiotti, Q., \& Singh, B. (2000). Adaptation in Canadian agriculture to climatic flooding variability and change. Climatic Change, 45, 181-201.

Bulkeley, H., Watson, M., \& Hudson, R. (2007). Modes of governing municipal waste. Environment and Planning $A$, 39(11), 2733-2753.

City of Mississauga. (2012). Backgrounder: City of Mississauga's stormwater program. City of Mississauga. Retrieved from http://www.mississauga. ca/file/COM/FINAL_Stormwater_management_back grounder_June_2012.pdf

City of Mississauga. (2017). Stormwater charge. City of Mississauga. Retrieved from http://www. mississauga.ca/portal/stormwater/charge

City of Toronto. (2007a). Implementing a mandatory downspout disconnection (AFS\# 3141). Toronto: City of Toronto. Retrieved from https://www.toronto.ca/ legdocs/mmis/2007/pw/bgrd/backgroundfile-7842. pdf

City of Toronto. (2007b). Public Works and Infrastructure Committee agenda. Toronto: City of Toronto. Retrieved from https://www.toronto.ca/legdocs/ mmis/2007/pw/agendas/2007-10-31-pw10-ar.pdf

City of Toronto. (2017a). Basement flooding protection subsidy program. City of Toronto. Retrieved from https://www.toronto.ca/services-payments/ water-environment/managing-rain-melted-snow/base ment-flooding/basement-flooding-protection-subsidy -program

City of Toronto. (2017b). Toronto green standard. City of Toronto. Retrieved from https://www.toronto. $\mathrm{ca} /$ city-government/planning-development/officialplan-guidelines/toronto-green-standard

City of Toronto. (2018). Mandatory downspout disconnection program. City of Toronto. Retrieved from https://www.toronto.ca/311/knowledgebase/kb/docs /articles/toronto-water/business-operations-manage ment/business-and-customer-support/mandatorydownspout-disconnection-program.html

Community Resilience to Extreme Weather. (2017). Extreme weather volunteers: Floor \& block captains. Community Resilience to Extreme Weather. Retrieved from http://www.crewtoronto.ca/ourprojects/floor-and-block-captains

Considine, M., \& Afzal, K. A. (2011). Legitimacy. In M. Bevir (Ed.), The Sage handbook of governance (pp. 369-385). London: Sage Publications.

Dewulf, A. (2013). Contrasting frames in policy debates on climate change adaptation. Wiley Interdisciplinary Reviews: Climate Change, 4(4), 321-330.

Dickinson, T., \& Burton, I. (2011). In J. D. Ford \& L. Berrang-Ford (Eds.), Climate change adaptation in developed nations: From theory to practice (pp. 103-117). Netherlands: Springer.

Dixon, J., \& Dogan, R. (2002). Hierarchies, networks and 
markets: Responses to societal governance failure. Administrative Theory \& Praxis, 24(1), 175-196.

Fleming, J., \& Rhodes, R. A. W. (2005). Bureaucracy, contracts and networks: The unholy trinity and the police. Australian \& New Zealand Journal of Criminology, 38(2), 192-205.

Frances, J., Levacic, R., Mitchell, J., \& Thompson, G. (1991). Introduction. In G. Thompson, J. Frances, R. Levacic, \& J. Mitchell (Eds.), Markets, hierarchies and networks: The coordination of social life (pp. 1-19). London: Sage Publications.

Hall, C. M. (2011). A typology of governance and its implications for tourism policy analysis. Journal of Sustainable Tourism, 19(4/5), 437-457.

Henstra, D. (2016). The tools of climate adaptation policy: Analyzing instruments and instrument selection. Climate Policy, 16(4), 496-521.

Henstra, D. (2017). Climate adaptation in Canada: Governing a complex policy regime. Review of Policy Research, 34(3), 378-399.

Huitema, D., Adger, W. N., Berkhout, F., Massey, E., Mazmanian, D., Munaretto, S., \& Termeer, C. (2016). The governance of adaptation: Choices, reasons, and effects. Ecology and Society, 21(3), 1-15.

Jessop, B. (2004). Multi-level governance and multi-level metagovernance. In I. Bache \& M. Flinders (Eds.), Multi-level governance (pp. 49-74). Oxford: Oxford University Press.

Jessop, B. (2011) Metagovernance. In M. Bevir (Ed.), The Sage handbook of governance (pp. 106-123). London: Sage Publications.

Levacic, R. (1991). Markets and government: An overview. In G. Thompson, J. Frances, R. Levacic, \& J. Mitchell (Eds.), Markets, hierarchies \& networks: The coordination of social life (pp. 35-47). London: Sage Publications.

Lonsdale, K., Pringle, P., \& Turner, B. (2015). Transformative adaptation: What it is, why it matters and what is needed. Oxford: UK Climate Impacts Program.

Manitoba Agriculture Risk Management Task Force. (2015). Agriculture risk management in Manitoba. Manitoba: Manitoba Agriculture Risk Management Task Force. Retrieved from https://www.gov.mb.ca/ agriculture/growing-forward-2/pubs/ag-risk-mgmttask-force-report-2015.pdf

Manitoba Agricultural Services Corporation. (2018). Agrilnsurance overview factsheet. Manitoba Agricultural Services Corporation. Retrieved from https:// www.masc.mb.ca/masc.nsf/program_agriinsurance. html

Marshall, A. (1991). On markets. In G. Thompson, J. Frances, R. Levacic, \& J. Mitchell (Eds.), Markets, hierarchies \& networks: The coordination of social life (pp. 24-34). London: Sage Publications.

Mees, H. L. P., Dijk, J., van Soest, D., Driessen, P. P. J., van Rijswick, M., \& Runhaar, H. (2014). A method for the deliberate and deliberative selection of policy instrument mixes for climate change adaptation. Ecology and Society, 19(2), 58-71.

Meuleman, L. (2008). Public management and the metagovernance of hierarchies, networks and markets: The feasibility of designing and managing governance style combinations. Heidelberg: Springer.

Miller, K. A., \& Belton, V. (2014). Water resources management and climate change adaptation: A holistic and multiple criteria perspective. Mitigation and Adaptation Strategies for Global Climate Change, 19(3), 289-308.

Mimura, N., Pulwarty, R., Duc, D. M., Elshinnawy, I., Redsteer, M. H., Huang, H. Q., \& Sanchez Rodriguez, R. A. (2014). Adaptation planning and implementation. In C. B. Field, V. R. Barros, D. J. Dokken, K. J. Mach, M. D. Mastrandrea, T. E. Bilir, . . . L. L. White (Eds.), Climate change 2014: Impacts, adaptation, and vulnerability. Contribution of Working Group II to the Fifth Assessment Report of the Intergovernmental Panel on Climate Change (pp. 869-898). Cambridge and New York: Cambridge University Press.

Natural Resources Canada. (2016). Canada's climate change adaptation platform: Equipping Canadians to adapt to a changing climate. Ottawa: Natural Resources Canada. Retrieved from: http://www.nrcan. gc.ca/sites/www.nrcan.gc.ca/files/oee/pdf/transport ation/tools/fuelratings/MasterListOCTOBER-2016Products-and-Projects-ENGLISH.pdf

Nederhand, J., Bekkers, V., Voorberg, W. (2016). Selforganization and the role of government: How and why does self-organization evolve in the shadow of hierarchy? Public Management Review, 18(7), 1063-1084.

Oulahen, G., Mortsch, L., Tang, K., \& Harford, D. (2015). Unequal vulnerability to flood hazards: "Ground truthing" a social vulnerability index of five municipalities in Metro Vancouver, Canada. Annals of the Association of American Geographers, 105(3), 473-495.

Parry, J., Taylor, S., Echeverria, D., McCandless, M., \& Gass, P. (2012). Manitoba's involvement in the Prairies Adaptation Collaborative-Synthesis report. Winnipeg: International Institute for Sustainable Development.

Pierre, J. (2000). Introduction. In J. Pierre (Ed.), Debating governance: Authority, steering, and democracy. New York, NY: Oxford University Press.

Pierre, J., \& Peters, B. G. (2000). Governance, politics and the state. New York, NY: St. Martin's Press.

Powell, W. W. (1991). Neither market nor hierarchy: Network forms of organization. In G. Thompson, J. Frances, R. Levacic, \& J. Mitchell (Eds.), Markets, hierarchies \& networks: The coordination of social life (pp. 265-276). London: Sage Publications.

Provan, K. G., \& Milward, H. B. (2001). Do networks really work? A framework for evaluating public-sector organizational networks. Public Administration Review, 61(4), 414-423.

Rhodes, R. A. (1997). From marketization to diplomacy: 
It's the mix that matters. Public Policy and Administration, 12(2), 31-50.

Rhodes, R. A. (2000). Governance and public administration. In J. Pierre (Ed.), Debating governance: Authority, steering, and democracy (pp. 54-90). New York, NY: Oxford University Press.

Steurer, R. (2013). Disentangling governance: A synoptic view of regulation by government, business, and civil society. Policy Sciences, 46(4), 387-410.

Sustainable South Osbourne. (2016). South Osbourne Permaculture Commons. Retrieved from http:// www.southosbornecommons.ca

Tenbensel, T. (2005). Multiple modes of governance: Disentangling the alternatives to hierarchies and markets. Public Management Review, 7(2), 267-288.

Thompson, G. (2003). Between hierarchies and markets: The logic and limits of network forms of organization. New York, NY: Oxford University Press.

Treib, O., Bahr, H., \& Falkner, G. (2007). Modes of governance: Towards a conceptual clarification. Journal of
European Public Policy, 14(1), 1-20.

Wellstead, A., Howlett, M., \& Rayner, J. (2013). The neglect of governance in forest sector vulnerability assessments: Structural-functionalism and "black box" problems in climate change adaptation planning. Ecology and Society, 18(3), 1-15.

Wellstead, A., Howlett, M., Nair, S., \& Rayner, J. (2016). "Push" dynamics in policy experimentation: Downscaling climate change adaptation programs in Canada. Climate Services, 4, 52-60.

Whelan, C. (2015). Managing dynamic public sector networks: Effectiveness, performance, and a methodological framework in the field of national security. International Public Management Journal, 18(4), 536-567.

Wolf, J., Adger, W. N., Lorenzoni, I., Abrahamson, V., \& Raine, R. (2010). Social capital, individual responses to heat waves and climate change adaptation: An empirical study of two UK cities. Global Environmental Change, 20(1), 44-52.

\section{About the Authors}

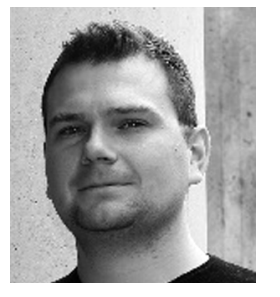

Danny Bednar is a PhD Candidate and Lecturer in the Department of Geography at Western University in London, Ontario, Canada. He holds a Bachelor of Arts degree with a double major in political science and environmental studies from the University of Winnipeg and a Master of Arts in Geography from Western University. His areas of research include climate change adaptation, governance, spacebased applications for environmental policy, and critical geopolitics.

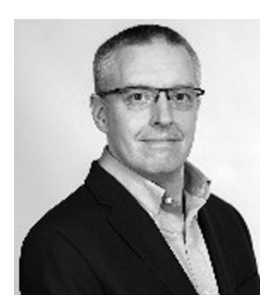

Daniel Henstra is Associate Professor of Political Science at the University of Waterloo and a Senior Fellow with the Centre for International Governance Innovation. His research centres on the multi-level governance of complex policy areas, such as climate change adaptation and flood risk management, with a focus on the networked relationships among elected officials, public servants, stakeholders and the public. 